\title{
KONTROVERSI EKSISTENSI FASHL DI ANTARA KOMPONEN IDHAFAH
}

\section{Fashl Existence Controversion between Idhafah Components}

$$
\text { وجود فاشل الخلاف بين مكونات الإضافة }
$$

\section{Muhammad Al Farabi}

Founder Qiraatpedia dan PTB, Indonesia

ayahqiraat@gmail.com

\begin{abstract}
Abstrak
Kesimpulan penelitian ini ialah eksistensi fashl (pemisah) antara mudhâf dan mudhâf ilaîh yang terdapat dalam qiraah Ibn 'Âmir merupakan cara yang terakomodir oleh salah satu pendapat sintaksis Arab. Spesifiknya, dikarenakan mudhâf dan mudhâf ilaîh merupakan manzilah syâ̂' wâhid (satu kesatuan), maka tidak diperkenankan hadirnya fashl di antara keduanya. Namun, qiraah Ibn 'Âmir asy-Syâmî meriwayatkan fashl di antara mudhâf dan mudhâf ilaîh yang mana transmisinya sahih serta memiliki argumentasi bahwa fashl di antara mudhâf dan mudhâf ilaîh nyatanya dapat ditemukan dalam kalam bangsa Arab.
\end{abstract}

Kata Kunci: Ibn ‘Âmir, sintaksis Arab, fashl, mudhâf, dan mudhâf ilaîh.

\section{Abstract}

The conclusion of this research is that the existence of fashl (separator) between mudhaf and mudhaf ilaîh contained in the qiraah of Ibn 'Âmir is a way that is accommodated by one of the Arabic syntactic opinions. Specifically, because mudhâf and mudhâf ilaîh are manzilah syaî' wâhid (one unit), the presence of fashl between the two is not allowed. However, the qiraah of Ibn 'mir asy-Syâmî narrated fashl between mudhaf and mudhaf ilaîh where the transmission is valid and has the argument that fashl between mudhaf and mudhaf ilaîh can in fact be found in the kalam of the Arabs.

Keywords: Ibn 'mir, Arabic syntax, fashl, mudhâf, and mudhâf ilaîh.

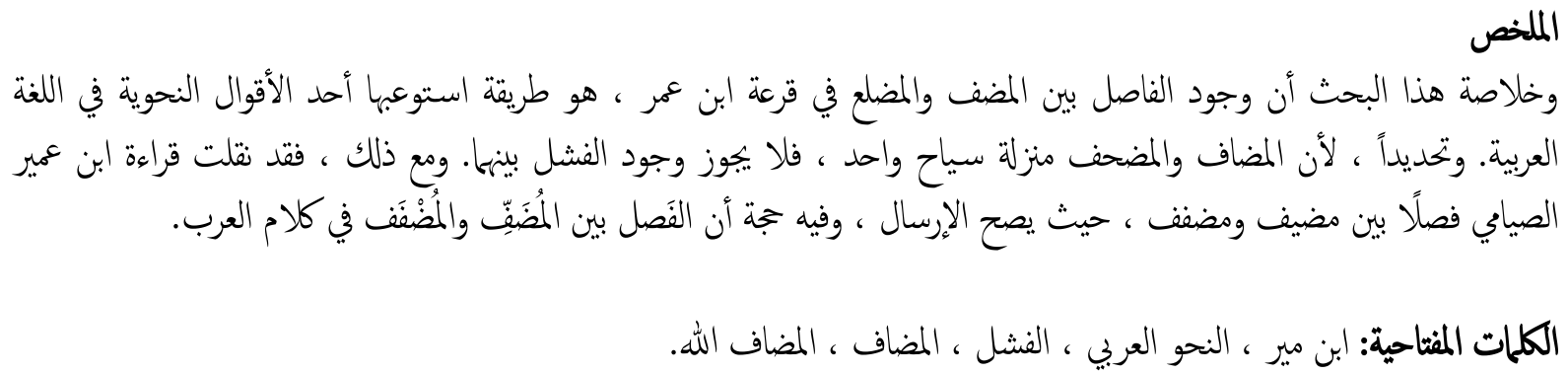

\section{Pendahuluan}

Qiraat Al-Qur'an telah mencuri perhatian segenap ahli sintakis Arab sejak lahirnya disiplin ilmu sintakis Arab yang biasa disebut ilmu nahu. Hal ini dianggap wajar lantaran tidak sedikit ahli sintaksis Arab di generasi awal merupakan ahli qiraat. 
Sebut saja 'Îsâ bin 'Umar ats-Tasaqafî dan Abû 'Amr al-Bashrî sebagai sampel. Bahkan, banyak juga ahli linguistik Arab yang telah terdidik di bidang Al-Qur'an dan qiraat sebelum terjun di bidang linguistik Arab, khususnya bidang sintakis Arab. ${ }^{1}$

Tatkala diskursus sintaksis Arab telah tersusun rapih secara kaidah dan telah dibukukan dengan sistematis, dilanjutkan dengan lahirnya Madrasah Basrah dan Madrasah Kufah, para ahli sintaksis kedua madrasah ini saling berlomba mengkaji qiraat guna memperkuat argumentasi sintaksis Arab yang telah dibangun oleh masing-masing madrasah. Tak hanya terbatas pada Madrasah Basrah dan Madrasah Kufah, para ahli sintaksis Arab independen (atau para ahli dari madrasah lain) juga terlibat dalam diskursus ini. Mereka saling memperkuat argumentasi masing-masing dan mendebat lawan madrasahnya menggunakan dalih yang bersumber dari qiraat. ${ }^{2}$ Namun, tak jarang para ahli linguistik Arab dan mufasir menemukan kesulitan dalam mendeskripsikan suatu kaidah sintaksis Arab dalam qiraat, khususnya pembahasan qiraat yang masuk kategori farsy (kaidah khusus yang hanya terdapat pada beberapa kata tertentu dalam Al-Qur'an). ${ }^{3}$ Hingga suatu fenomena yang tak diharapkan akhirnya terjadi. Fenomena itu ialah munculnya protes yang dilayangkan kepada imam qiraat serta pengingkaran terhadap qiraat imam terkait yang dinilai tidak sejalan dengan norma kaidah sintaksis Arab yang berlaku. ${ }^{4}$ Padahal, bisa jadi protes yang dilayangkan ternyata tidak diamini oleh kubu madrasah sintaksis Arab lainnya.

Qiraah Ibn 'Âmir merupakan salah satu qiraat yang tak bisa dipisahkan dari dinamika sintaksis Arab. Tak sedikit ahli sintaksis Arab dan mufasir yang menyoroti cara baca yang diriwayatkannya. Secara das sollen, qiraah Ibn 'Âmir merupakan qiraah yang telah disepakati oleh aklamasi pakar qiraat sebagai salah satu dari qirâ' ât 'asyr (sepuluh mazhab tata cara baca Al-Qur'an) yang mutawâtir (valid). ${ }^{5}$ Bila dikerucutkan, beliau merupakan salah satu imam dari qirâ'ât sab' (tujuh mazhab tata cara baca Al-Qur'an). ${ }^{6}$ Qiraah Ibn 'Âmir merupakan satu dari tiga qiraat yang paling dekat transmisinya dengan Nabi Muhammad SAW, tepatnya qiraah Ibn 'Âmir yang diriwayatkan oleh Ibn Dzakwân. ${ }^{7}$ Ibn 'Âmir juga merupakan imam qirâ'ât 'asyr yang paling senior usianya, karena beliau telah berumur dua tahun saat Nabi Muhammad SAW wafat, ${ }^{8}$ sedangkan saat itu belum ada imam qiraat lainnya yang terlahir di muka bumi.

\footnotetext{
' 'Abd al-Hâfizh Hasan Mushthafâ al-'Usailî, "Qirâ'ah Ibn 'Âmir: Qatl Awlâdahum Syurakâ'ihim”, Majallah Kuliyyah al-Lughah al-'Arabiyyah bi al-Manûfiyyah, Vol. 13, 1992, 553.

2 'Abd al-Hâffizh Hasan Mushthafâ al-'Usailî, "Qirâ'ah Ibn “Âmir: Qatl Awlâdahum Syurakâ' ihim”, $553-554$.

${ }^{3}$ Hâtim bin 'Âbid al-Qurasyî, "Daf ali'tirâdh 'an Qirâ'ah Ibn 'Âmir: Zuyyin li Katsîr min alMusyrikîn Qatl Awlâdahum Syurakâ' ihim”, Jurnal Dâr al-Manzhûmah o4, no. 6 (2015): 5.

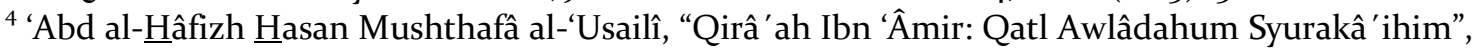
554 .

${ }^{5}$ Sya'bân Muhammad Ismâ'îl, Al-Qirâ'ât; Ahkâmuhâ wa Mashdaruhâ (Kairo: Dâr as-Salâm, cet. ke-4, 2008), 75.

${ }^{6}$ Al-Qâsim bin Fîrruh asy-Syâthibî, Hirz al-Amânî wa Wajh at-Tahânî (Madinah: Maktabah Dâr Ibn al-Jazarî, 2011), 2-3.

${ }^{7}$ Muhammad Ibn al-Jazarî, an-Nasyr fi al-Qirâ 'ât al-'Asyr (Kairo: Maktabah ash-Shafâ, 2014), 263.

${ }^{8}$ Muhammad adz-Dzahabî, Ma'rifah al-Qurrâ' al-Kibâr (Tanta: Dâr ash-Shahâbah li at-Turâts, 2008), 62 .
} 
Terakhir, dalam tatanan qirâ'ât 'asyr, hanya ada dua imam qiraat yang asli Arab. Salah satu dari dua imam tersebut ialah Ibn 'Âmir. ${ }^{9}$ Namun secara das sein, tidak sedikit mufasir dan ahli sintaksis Arab yang menyangsikan beberapa format bacaan yang terkandung dalam qiraah ini. Bahkan mereka tak sungkan melabeli beberapa format bacaan Ibn 'Âmir sebagai suatu cara baca yang qabîh (buruk) secara sintaksis Arab. Salah satu indikatornya ialah faktor munfarid (tunggalnya) cara baca qiraah Ibn 'Âmir di beberapa tempat yang kontras dengan qiraat lain yang berkaitan erat dengan khilafiah internal ahli sintaksis Arab.

\section{Transmisi Qiraah Ibn ‘Âmir}

Terdapat banyak data yang merekam nama-nama guru Ibn 'Âmir. Di bidang AlQur'an, seluruh guru beliau merupakan Sahabat Nabi, baik secara data benar-benar menjadi guru Ibn 'Âmir asy-Syâmî atau ternyata bukan menjadi gurunya. Berikut ini penjabarannya:

1. Al-Mughîrah bin Abî Syihâb. Ini merupakan transmisi beliau yang paling valid ${ }^{10}$ lantaran memang Ibn 'Âmir membaca Al-Qur'an kepada al-Mughîrah bin Abî Syihâb. ${ }^{11}$

2. Abû ad-Dardâ'. Ibn 'Âmir membaca Al-Qur'an kepada Abû ad-Dardâ'.' ${ }^{2}$ Ini

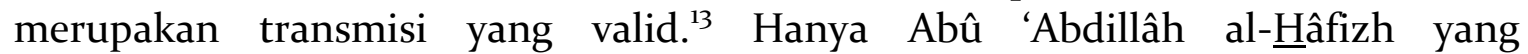
menyangsikan validitas transmisi ini, namun beliau tidak memiliki argumentasi yang kuat atas keraguannya ini. ${ }^{14}$

3. Fadhâlah bin 'Ubaîd. Ibn al-Jazarî berkata: "Data mengenai Ibn 'Âmir membaca AlQur'an kepada Fadhâlah bin 'Ubaîd merupakan data yang baik (jayyid)”. ${ }^{15}$

4. 'Utsmân bin 'Affân. Berikut ini rinciannya:

a. "Beliau mengaku pernah mendengar 'Utsmân bin 'Affân membaca penggalan

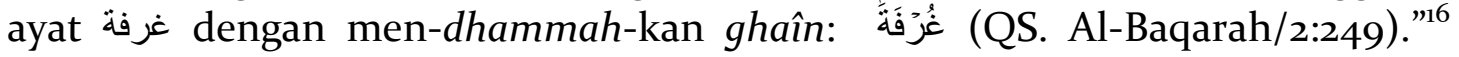
Komentar Ibn al-Jazarî: "Kemungkinan benar dan salahnya berita ini seimbang (muhtamal)" ${ }^{17}$

b. "Ibn 'Âmir membaca sebagian (ba'dh) Al-Qur'an kepada 'Utsmân bin 'Affân, lebih tepatnya lebih dari separuh Al-Qur'an." ${ }^{\text {"8 }}$ Data ini bisa saja benar."

c. "Ibn 'Âmir membaca seluruh Al-Qur'an kepada 'Utsmân bin 'Affân.” Data ini tidak valid. ${ }^{20}$

${ }^{9}$ Muhammad ad-Dusûqî Amîn Kahîlah, Syarh asy-Syâthibiyyah (Kairo: Dâr as-Salâm, 2013), 17 dan Anwar Shubhî Muhammad 'Âbidîn, alikhtishâr fí al-Qirâ' ât al-'Asyr (Tanta: Dâr ash-Shahâbah li atTurâts), 11.

${ }^{10}$ Muhammad Ibn al-Jazarî, Ghâyah an-Nihâyah fî Thabaqât al-Qurrâ', 591.

${ }^{11}$ Ibn al-Wajîh al-Wâsithî, al-Kanz fì al-Qirâ'ât al-'Asyr, cet. ke-1 (Beirut: Dâr al-Kutub al'Ilmiyyah, 1998), 23.

${ }^{12}$ Abû 'Amr ad-Dânî, at-Taisîr fî al-Qirâ 'ât as-Sab' (Tanta: Dâr ash-Shahâbah li at-Turâts, 2006),

9 .

${ }^{13}$ Muhammad Ibn al-Jazarî, an-Nasyr fì al-Qirâ' ât al-'Asyr, 263.

${ }^{14}$ Muhammad Ibn al-Jazarî, Ghâyah an-Nihâyah fì Thabaqât al-Qurrâ', 592.

${ }^{15}$ Muhammad Ibn al-Jazarî, Ghâyah an-Nihâyah fî Thabaqât al-Qurrâ', 592.

${ }^{16}$ Muhammad adz-Dzahabî, Ma'rifah al-Qurrâ' al-Kibâr 65.

${ }^{17}$ Muhammad Ibn al-Jazarî, Ghâyah an-Nihâyah fî Thabaqât al-Qurrâ', 592.

${ }^{18}$ Muhammad adz-Dzahabî, Ma'rifah al-Qurrâ' al-Kibâr, 65.

${ }^{19}$ Muhammad Ibn al-Jazarî, Ghâyah an-Nihâyah fì Thabaqât al-Qurrâ', 592.

${ }^{20}$ Muhammad Ibn al-Jazarî, Ghâyah an-Nihâyah fì Thabaqât al-Qurrâ', 593. 
5. Wâtsilah bin al-Asqa'. ${ }^{21}$ Tidak ada riwayat yang menentang berita Ibn 'Âmir membaca Al-Qur'an kepada Wâtsilah bin al-Asqa'. ${ }^{22}$

6. An-Nu'mân bin Basyîr. ${ }^{23}$ Penulis belum menemukan sanggahan atau komentar seputar bacaan Ibn 'Âmir kepada an-Nu'mân bin Basyîr.

7. Mu'âwiyah bin Abî Sufyân. Data mengenai bacaan Al-Qur'an Ibn 'Âmir kepada Mu'âwiyah nyatanya tidak valid. ${ }^{24}$

8. Mu'âdz bin Jabal. ${ }^{25}$ Data mengenai bacaan Al-Qur'an Ibn 'Âmir kepada Mu'âdz Ini merupakan data yang daif. $^{26}$

9. 'Alî bin Abî Thâlib.

10. 'Abdullâh bin Mas'ûd.

11. Zaîd bin Tsâbit. Diriwayatkan bahwa ketika di Madinah, Ibn 'Âmir menjumpai 'Alî bin Abî Thâlib, 'Abdullâh bin Mas'ûd, dan Zaîd bin Tsâbit serta mendengar bacaan Al-Qur'an mereka. Namun berita ini nyatanya tidak sahih ${ }^{27}$

12. Rajul (seseorang). Ibn 'Âmir menyatakan bahwa ia membaca Al-Qur'an kepada "seseorang" yang membaca Al-Qur'an kepada 'Ustmân bin 'Affân. ${ }^{28}$ Ibn Dzakwân selaku pewarta tidak menyebutkan nama sosok tersebut. Yang menyebutkan nama sosok ini adalah Hisyâm. ${ }^{29}$ Beliau meriwayatkan dari 'Irâk dan Suwâid bahwa sosok tersebut adalah al-Mughîrah bin Syihâb. ${ }^{30}$

Walaupun seluruh gurunya merupakan sahabat, namun tak semua sahabat tersambung transmisinya langsung kepada Nabi Muhammad SAW. Dari nama-nama yang benar-benar menjadi gurunya, yang transiminya tersambung langsung kepada Nabi Muhammad SAW ialah Abû Dardâ' dan 'Utsmân bin 'Affân. Sehingga, antara Ibn 'Âmir dengan Nabi Muhammad SAW hanya terpisah satu generasi.

\section{Fashl di antara Mudhâf dan Mudhâf ilaîh}

Dalam QS. Al-An'âm/6:137, Allah SWT berfirman:

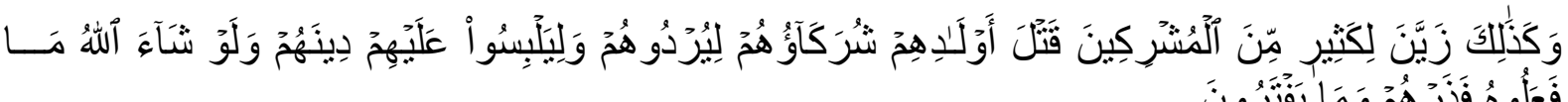

Demikian pula para sekutu kaum musyrikin mengiming-imingkan keindahan kepada kebanyakan dari mereka untuk membunuh anak-anak mereka agar mereka binasa dan mengacaukan agama mereka sendiri. Bila Allah SWT berkehendak, niscaya mereka

${ }^{21}$ Muhammad bin al- Husaîn al-Qalânisî, Irsyâd al-Mubtadî wa Tadzkirah al-Muntahî cet. ke-1, (Beirut: Dâr al-Kutub al-'Ilmiyyah, 2007), 79.

${ }^{22}$ Muhammad Ibn al-Jazarî, Ghâyah an-Nihâyah fî Thabaqât al-Qurrâ', 592.

${ }^{23}$ Muhammad bin al-Husaîn al-Qalânisî, Irsyâd al-Mubtadî wa Tadzkirah al-Muntahî, 79.

${ }^{24}$ Muhammad Ibn al-Jazarî, Ghâyah an-Nihâyah fî Thabaqât al-Qurrâ', 592.

${ }^{25}$ Al-Mubârak asy-Syahrazûrî, al-Mishbâh az-Zâhir, cet. ke-1 (Beirut: Dâr al-Kutub al-'Ilmiyyah, 2008), 124.

${ }^{26}$ Muhammad Ibn al-Jazarî, Ghâyah an-Nihâyah fi Thabaqât al-Qurrâ', 591-592.

${ }^{27}$ Muhammad adz-Dzahabî, Ma'rifah al-Qurrâ' al-Kibâr, 63.

${ }^{28}$ Abû 'Alî al-Hasan al-Ahwâzî, al-Wajîz (6Beirut: Dâr al-Gharb al-Islâmî), 8.

${ }^{29}$ Abû Bakr bin Mihrân al-Ashfahânî, al-Mabsûth fí al-Qirâ'ât al-'Asyr (Jeddah: Dâr al-Qiblah li ats-Tsaqâfah al-Islâmiyyah, 1998). 44.

$3^{0}$ Abû Ja'far Aḥmad al-Anshârî, al-Iqnâ' fì al-Qirâ'ât as-Sab' (Tanta: Dâr ash-Shahâbah li atTurâts, 2003), 33 . 
tidak akan melakukan perbuatan itu. Maka, biarkanlah mereka dan biarkanlah apa saja yang mereka kerjakan.

Qiraah Ibn 'Âmir asy-Syâmî merupakan satu-satunya qirâ 'ât 'asyr yang membaca dengan cara yang berbeda, yakni:

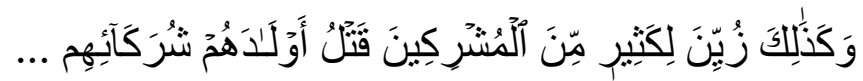

Dengan rincian: pertama, menggunakan bentuk majhûl (kalimat pasif) pada fi'l زَ, yakni dengan men-dhammah-kan zây dan mengkasrahkan yấ'; kedua, memposisikan kata 话 sebagai fầil, yakni men-dhammah-kan lâm, sekaligus menjadi mudhâf $\beta^{1}$; ketiga, memposisikan kalimat أَوَلَّدِهِ sebagai mafûl (objek), yakni memfathah-kan dâl serta men-dhammah-kan hâ', dan; keempat, men-khafdh-kan kalimat شُرَكَأَهُ هُمْ

Problem yang menjadi sorotan ayat ini ialah adanya fashl (pemisah) menggunakan zharf $\beta^{2}$ atau rangkaian $k h a f d h^{33}$ dan makhfûdh antara mudhâf dan mudhâf ilaîh yang mana dalam ucapan biasa (di luar Al-Qur'an dan syair) saja sudah terlarang, apalagi menggunakan mafûl $b i h^{34}$ yang statusnya lebih tidak layak dibanding zharf dan khafdh. Bagaimana pula dapat diterima bila ternyata format ini terdapat pada kalam yang paling fasih, yakni Al-Qur'an. ${ }^{35}$

Berangkat dari realita ini, munculah tha'n (cercaan) yang dialamatkan ke format fashl ala qiraah Ibn 'Âmir asy-Syâmî. Adapun sosok yang dianggap sebagai orang pertama dalam mencerca qiraah Ibn 'Âmir asy-Syâmî serta qiraat lainnya adalah Ibn Jarîr ath-Thabarî (224-310 H); sang mufasir kenamaan. ${ }^{36}$ Ibn Jarîr ath-Thabarî berkata: "Sebagian qari penduduk Syam membaca وَكَذَلِكَ زَيَّنَ dengan men-dhammah-kan zây,

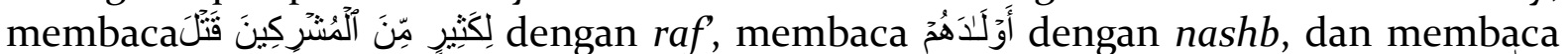

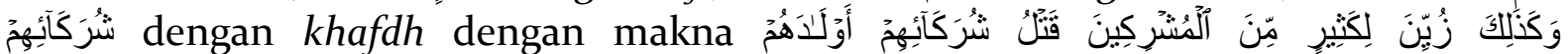
(demikianlah kebanyakan orang-orang musyrik telah diiming-imingi agar para sekutu mereka membunuh anak-anak mereka). Mereka (sebagian qari penduduk Syam)

${ }^{31}$ Mudhâf adalah isim pertama dalam komponen idhâfah, sedangkan mudhâf ilaîh adalah ism kedua. Idhâfah sendiri secara etimologi berarti muthlaq al-Isnâd (penyandaran secara absolut). Adapun secara terminologi, idhâfah ialah penyandaran suatu isim kepada isim lainnya yang mana isim kedua berposisi layaknya tanwîn bagi ism pertama. Lihat: Muhammad al-Ahdal, al-Kawâkib ad-Durriyyah 'alâ Mutammimah al-Âjurrûmiyyah, cet. ke-2, (Kairo: Maktabah al-Hady al-Muhammadî, 2016), 386.

${ }^{2}$ Madrasah Basrah menamainya dengan zharf az-Zamân (isim yang menunjukkan makna waktu) dan zharf al-Makân (isim yang menunjukkan makna tempat) karena aktivitas terkait tidak dapat terlepas dari dimensi waktu atau tempat. Sedangkan Madrasah Kufah menamainya mafûl fih (objek dalam lingkupnya), mahall (tempat), atau shifah (sifat). Lihat: Muhammad al-Ahdal, al-Kawâkib adDurriyyah 'alâ Mutammimah al-Âjurrûmiyyah (Kairo: Maktabah al-Hady al-Muhammadî, 2016), 301.

${ }^{33}$ Khafdh yang secara harfiah bermakna "bawah/rendah" adalah suatu perubahan (akhir kata) yang ditandai dengan kasrah atau penggantinya. Khafdh hanya ditemukan di isim. Lihat: Muhammad Muhyî ad-Dîn 'Abd al-Hamîd, at-Tuhfah as-Saniyyah bi Syarh al-Muqaddimah al-Âjurrûmiyyah, Kairo: Dâr ath-Thalâ'i', 2009, hal. 19. Khafdh merupakan istilah yang digunakan Madrasah Kufah, sedangkan jarr merupakan istilah yang digunakan Madrasah Basrah. Lihat: Muhammad al-Ahdal, al-Kawâkib adDurriyyah 'alâ Mutammimah al-Âjurrûmiyyah, cet. ke-2 (Kairo: Maktabah al-Hady al-Muhammadî, 2016), 16.

${ }^{34}$ Mafûl bih adalah isim yang menjadi objek/sasaran aktivitas fiil. Lihat: Muhammad al- $\underline{\text { Hathtâb, }}$ Mutammimah al-Âjurrûmiyyah, cet. ke-2 (Riyadh: Dâr ash-Shumay'î li an-Nasyr wa at-Tauzî', 2017 ), 71.

35 'Abd al-'Azîz bin 'Alî al-Harbî, Taujîh Musykil al-Qirâ'ât al-'Asyriyyah al-Farsyiyyah, cet. ke-1, (Beirut: Dâr Ibn Hazm, 2012), 230.

${ }^{36}$ Muhammad Ibn al-Jazarî, an-Nasyr fí al-Qirâ 'ât al-'Asyr, 58. 
memisah khâfidh (kata yang berfungsi meng-khafdh-kan kata lain) dan makhfûdh (kata yang dipengaruhi oleh khâfidh) selaku oknum yang mengerjakan perbuatan keji (pembunuhan) yang mana dalam kalam Arab narasi tersebut merupakan narasi qabîh (buruk) yang ghaîr fashîh (tidak fasih). Walaupun sebagian penduduk Hijaz mewartakan sebuat bait syair yang mendukung qiraah Syam tersebut, namun sesuai observasiku bahwa para pewarta syair dan ahli linguistik negeri Irak mengingkari

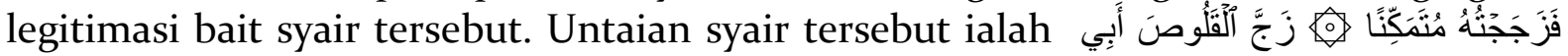

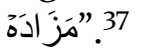

Maksud bait ini ialah terpisahnya kata زَجَّ selaku mudhâf dan kata أَبِي selaku mudhâf ilaîh dengan kalimat أْقَلْصَ selaku mafûl bih. Ibn Jarîr ath-Thabarî hanya memperkenankan bacaan mutawâtir yang diriwayatkan oleh selain qiraah Ibn 'Âmir asy-Syâmî dengan dalih bahwa شُرَكَأَُْهُمْ (para sekutu) merupakan oknum yang memberi iming-iming kaum musyrikin untuk menghabisi anak-anak mereka, bukan sebagai pelaku pembunuhan anak-anak musyrikin. Sedangkan qiraah Ibn 'Âmir asy-Syâmî menggiring persepsi bahwa yang membunuh adalah para sekutu kaum musyrikin. ${ }^{38}$

Benang merah dari pendapat Ibn Jarîr ath-Thabarî ini adalah tafsiran beliau

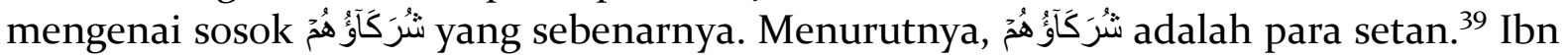
Katsîr ad-Dimasyqî (701-774 H) juga sependapat dengan Ibn Jarîr ath-Thabarî, yakni شُرَكَأَُ هُْْ awal oleh Mujâhid bin Jabr (W. 103 atau 102 H) dalam kitab tafsirnya. ${ }^{41}$ Sedangkan dalam Tafsîr al-Jalâlaîn disebutkan bahwa شُرَكَأَعُ هُمْ adalah para sekutu dari bangsa jin. ${ }^{42}$

Berikutnya, Jârullâh az-Zamakhsyarî $(467-538 \mathrm{H})$ turut mengomentari bacaan ini: "Bila ada suatu kaidah yang dalam kondisi darurat (yakni dalam syair) saja sudah samj (buruk) dan mardûd (tertolak) sebagaimana buruknya dan tertolaknya narasi زَجَّ أَلَقُوَوَ أَبِي مَزَادًََ , maka bagaimana statusnya bila diletakkan di kalam mantsûr (ucapan yang tak bersajak)? Bagaimana juga bila disematkan dalam Al-Qur'an selaku mukjizat yang indah susunannya?" 43 Maksud dari pernyataan ini ialah bila suatu kaidah sintaksis Arab yang dalam syair saja sudah tidak layak, bagaimana mungkin dapat diaplikasikan dalam Al-Qur'an yang telah dipastikan kesakralannya.

Menurut Abû 'Alî al-Fârisî (377 H), kalimat شُرَكَاؤُهُ هُ tidak bisa menjadi fầil dari kata merupakan sasaran dari tindakan kebanyakan orang-orang musyrik telah diiming-imingi agar para sekutu mereka membunuh anak-anak mereka”. Yang demikian ini merupakan cara qabîh dan qalîl alisti'mâl (sedikit penggunannya). ${ }^{44}$

Ia juga sependapat dengan Ibn Jarîr ath-Thabarî mengenai شُرَكَأَُُْْ bukanlah sebagai pelaku pembunuhan, melainkan sosok yang mengiming-iming terjadinya

${ }^{37}$ Ibn Jarîr ath-Thabarî, Tafsîr ath-Thabarî, cet. ke-4, jld. 4 (Kairo: Dâr as-Salâm, 2009), 3354.

${ }^{38}$ Ibn Jarîr ath-Thabarî, Tafsîr ath-Thabarî, 3355.

${ }^{39}$ Ibn Jarîr ath-Thabarî, Tafsîr ath-Thabarî, 3353 .

${ }^{40}$ Ibn Katsîr ad-Dimasyqî, Tafsîr al-Qur'ân al-'Azhîm, jld. 2 (Beirut: Dâr al-Fikr, 2005), 700.

${ }^{41}$ Mujâhid bin Jabr, Tafsîr al-Imâm Mujâhid bin Jabr, cet. ke-1, 1 (Kairo: Dâr al-Fikr al-Islâmî alHadîtsah, 1989), 328 .

${ }^{42}$ Jalâl ad-Dîn al-Mahallî dan Jalâl ad-Dîn as-Suyûthi, Tafsîr al-Jalâlaîn, dalam Ash-Shâwî, Hâsyiyah ash-Shâwî (Beirut: Dâr al-Fikr, 2004), 61.

${ }^{43}$ Jârullâh Az-Zamakhsyarî, Tafsîr al-Kasysyâf (Beirut: Dâr al-Ma'rifah), 348.

${ }^{44}$ Abû 'Alî al-Fârisî, al-ㅂujjah li al-Qurrâ' as-Sab'ah, cet. ke-2, (Riyadh: Maktabah ar-Rusyd, 2018), $410-411$. 
pembunuhan yang dilakukan kaum musyrikin. ${ }^{45}$ Beliau juga sejalan dengan Jârullâh az-Zamakhsyarî yang menyatakan bahwa dalam percakapan biasa saja, zharaf tidak digunakan sebagai fashl, padahal zharf merupakan kaidah yang paling dinamis; dapat menempati posisi yang tidak boleh diisi oleh kaidah lain. Misalnya dalam bab إِّ ; yang boleh menjadi fashl antara أَنَّإِنَّ dengan isimnya hanylah zharf yang bersatus sebagai khabar ${ }^{46}$. Contoh: 47

GIbn Khâlawaîh yang mengatakan bahwa bacaan qiraah Ibn 'Âmir asy-Syâmî ini qabîh bila digunakan untuk redaksi Al-Qur'an. Namun, beliau mengamini bahwa adanya bacaan tersebut berasal dari tulisan mushaf penduduk Syam yang menggunakan yâ' (yang menjadi penopang huruf hamzah); سركانهم.

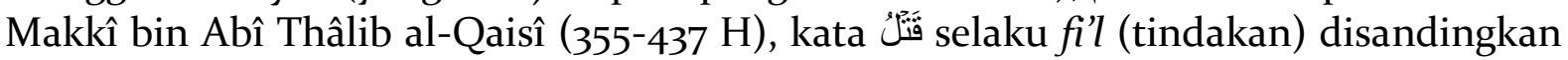

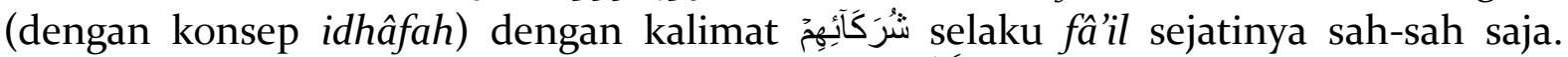
Namun, saat keduanya di-fashl oleh kalimat أَوَلََدَهُْْرَ selaku mafûl bih (objek) yang berstatus muta'akhkhir fí al-Ma'nâ (diakhirkan dari perspektif makna), maka qiraah ini layak diklaim sebagai bacaan yang daif. Karena sejatinya kaidah ini dilegalkan dalam syair, asalkan fashl-nya berupa zharf. Adapun bila fashl berupa mafûl bih, maka dalam ranah syair pun sudah berstatus ba'îd (jauh "dari cara yang benar"), apalagi dalam Al-Qur'an, maka statusnya ab'ad (lebih jauh). ${ }^{49}$

Terakhir, al-Kalbî $(741 \mathrm{H})$ mengungkapkan fakta yang mengejutkan. Beliau menyatakan bahwa qiraah Ibn 'Âmir asy-Syâmî ini sejatinya juga diriwayatkan oleh Ibn 'Abbâs. Namun, fakta ini tak membuat al-Kalbî gentar. Beliau tetap mengklaim bacaan ini sebagai bacaan yang daif dalam kaidah linguistik Arab. ${ }^{50}$

\section{Reaksi Madrasah Basrah}

Jumhur pakar Madrasah Basrah melarang terjadinya fashl menggunakan mafûl bih antara mudhâf dan mudhâf ilaîh selain di ranah syair..$^{51}$ Pelarangan yang dikemukakan mayoritas ahli Madrasah Basrah berangkat dari fakta bahwa mudhâf dan mudhâf ilaîh merupakan manzilah syaî̀' wâhid (satu kesatuan). Namun, mudhâf dan mudhâf ilaîh boleh dipisah sebagaimana syair yang ditembangkan oleh 'Amr bin Qamî'ah (W. $85 \mathrm{SH}$ ):

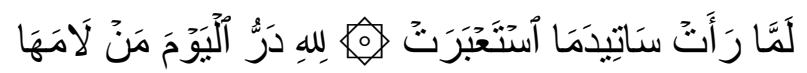

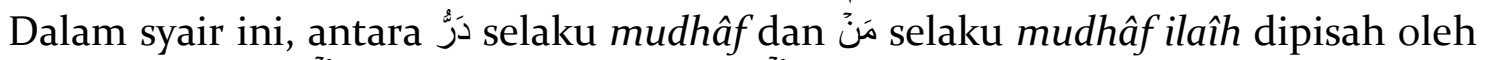

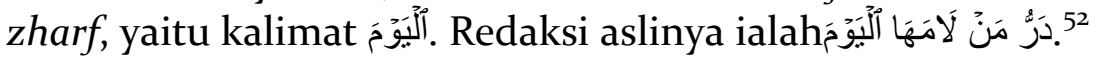

Sîbawaîh (W. 180 H) dalam kitabnya menampilkan qiraah lain dari ayat ini. Redaksinya ialah:

${ }^{45}$ Abû 'Alî al-Fârisî, al-Hujjah li al-Qurrâ' as-Sab'ah, 410.

${ }^{46}$ Khabar adalah bagian yang berfungsi sebagai penyempurna faedah. Lihat: Ibn Mâlik, Alfiyyah Ibn Mâlik dalam Muhammad bin 'Alî ash-Shabbân, Hâasyiyah ash-Shabbân, jld. 1 (Beirut: Dâr al-Kutub al-'Ilmiyyah, 2005), 284.

${ }^{47}$ Abû 'Alî al-Fârisî, al- $\underline{H u j j a h ~ l i ~ a l-Q u r r a ̂ ' ~ a s-S a b ' a h, ~ 411-412 . ~}$

${ }^{48}$ Ibn Khâlawaîh, al-Hujjah fí al-Qirâ 'ât as-Sab' (Kairo: Dâr Ibn al-Jauzî, 2013), 71.

49 Makkî bin Abî Thâlib al-Qaisî, Kitâb al-Kasyf 'an Wujûh al-Qirâ'ât as-Sab' wa 'Ilalihâ wa Hujajihâ, cet. ke-1, (Beirut: Mu'assasah ar-Risâlah, 2014), 453-454.

${ }^{\circ}$ Abû al-Qâsim al-Kalbî, at-Tashîl li 'Ulûm at-Tanzîl cet. ke-1, jld. 1 (Beirut: Dâr al-Kutub al'Ilmiyyah, 1995), 287.

${ }^{51}$ Muhammad Ibn al-Jazarî, an-Nasyr fí al-Qirâ'ât al-'Asyr, 57.

${ }^{22}$ Abû al-Barakât al-Anbârî, al-Inshâffî Masâ'il al-Khilâf, cet. ke-3, jld. 1 (Beirut: Dâr al-Kutub al'Ilmiyyah, 2016), 385-384. 


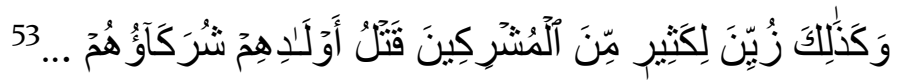

Kata شُرَكَأَُُهُ هُنْ

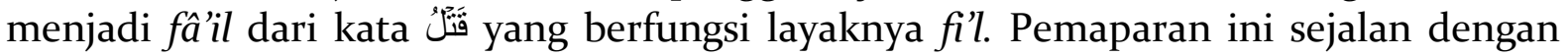
pendapat Quthrub (W. 206 H), namun tidak dengan Sîbawaîh, karena menurutnya,

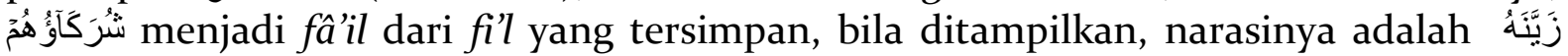

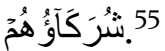

Qiraah ini diriwayatkan oleh Abû 'Abd ar-Raḩmân as-Sulamî (W. $74 \mathrm{H})^{56}$ yang pada realitanya tidak diturunkan kepada muridnya yang kelak menjadi imam qiraah; 'Âshim al-Kûfi (W. 129 H). Sedangkan menurut Ibn 'Athiyyah, bacaan ini diriwayatkan bukan hanya oleh Abû 'Abd ar-Rahmân as-Sulamî, melainkan juga diriwayatkan oleh al-Hasan dan Abû 'Abd al-Malik. ${ }^{57}$ Sedangkan al-Hadzalî (W. $465 \mathrm{H}$ ) menyebutkan

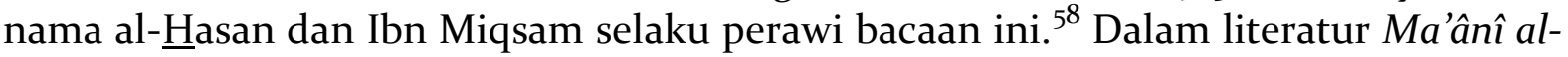
Qur'ân wa I'râbuh, sang penulis; az-Zajiâj (230-311 H), walau tidak memaparakan sanggahan mengenai fashl pada QS. Al-An'âm/6:137, namun beliau membahasnya di tempat lain, tepatnya di QS. Ibrâhîm/14:47/51:

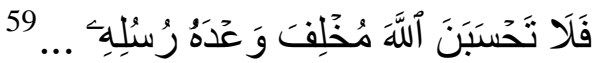

Az-Zajjâj tidak menyebutkan nama qari yang meriwayatkan bacaan ini. Beliau hanya mengatakan bahwa bacaan ini masuk kategori syâdzdz (tidak mutawâtir) serta radî'ah (buruk). Beliau juga mengatakan bawah mudhâf dan mudhâf ilaîh tidak boleh terpisah. $^{60}$ Namun, nyatanya ada dua figur dari madrasah ini yang tidak sejalan dengan pendapat mayoritas: pertama, al-Akhfasy (W. $211 \mathrm{H}$ ), beliau membolehkan fashl secara absolut ${ }^{61}$ dan kedua, Abû 'Ubaidah (110-213 H), beliau pernah mendengar beberapa orang Arab berkata:

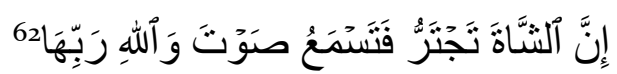

Maksudnya, antara صَوَتَّ selaku mudhâf dan redaksi رَبَّ selaku mudhâf ilaîh dipisah oleh redaksi وَاَْلَ yang merupakan redaksi sumpah.

\section{Reaksi Madrasah Kufah}

Madrasah Kufah melegalkan fashl tanpa menggunakan kaidah zharf atau huruf khafdh antara mudhâf dan mudhâf ilaîh pada ranah syair. Kebolehakn ini berlandaskan

53 'Amr bin 'Utsmân bin Qanbar, Kitâb Sîbawaîh, cet. ke-6, jld. 1 (Kairo: Maktabah al-Khânjî, 2013), 290.

54 Abû al-Baqâ' al-'Ukbarî, I'râb al-Qirâ'ât asy-Syawâdz (Tanta: Dâr ash-Shahâbah li at-Turâts, 2009), 126.

55 Ibn 'Athiyyah, al-Muharrar al-Wajîz fî Tafsîr al-Kitâb al-'Azîz (cet. ke-1, jld. 2 (Beirut: Dâr alKutub al-'Ilmiyyah, 2001), 349 dan Abû Hayyân, Tafsîr al-Bahr al-Muhîth, cet. ke-1, jld. 4 (Beirut: Dâr alKutub al-'Ilmiyyah, 1993), 231.

${ }^{56}$ Ibn Jinnî, al-Muhtasab (t.tp: Dâr Sazkîn, 1986), 229.

${ }^{57}$ Ibn 'Athiyyah, al-Muharrar al-Wajîz fî Tafsîr al-Kitâb al-'Azîz, 349.

$5^{8}$ Abû al-Qâsim Yûsuf al-Hadzilî, al-Kâmil fî al-Qirâ'ât al-Khamsîn cet. ke-1, jld. 4 (Kairo: Maktabah Aulâd asy-Syaîkh li at-Turâts, 2016), 217.

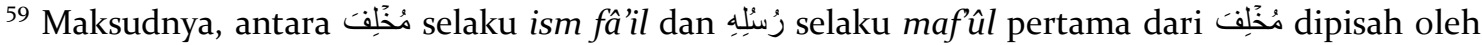
وَ عَدَهُ yang berstatus sebagai mafûl pertama. Penj.

${ }^{60}$ Abû Ishâq az-Zajjâj, Ma'ânî al-Qur'ân wa I'râbuh, cet. ke-1, jld. 3 (Beirut: 'Âlam al-Kutub, 1988), 168.

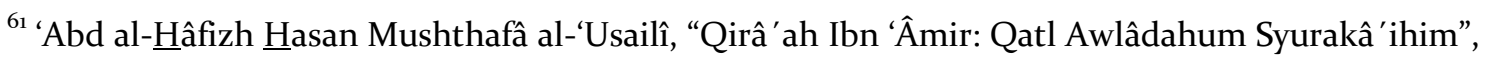
583.

${ }^{62}$ Abû al-Barakât al-Anbârî, al-Inshâffî Masấ'il al-Khilâf, 385. 
argumen bahwa kalangan Arab banyak menggunakan fashl selain kaidah zharf atau huruf khafd. Di antaranya ialah syair berikut ini:

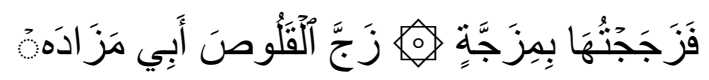

Dalam syair di atas, antara زَ زَجَّ selaku mudhâf dan أَبِ selaku mudhâf ilaîh dipisah

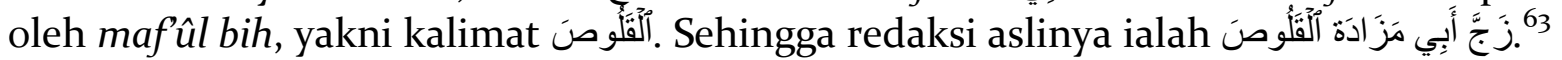

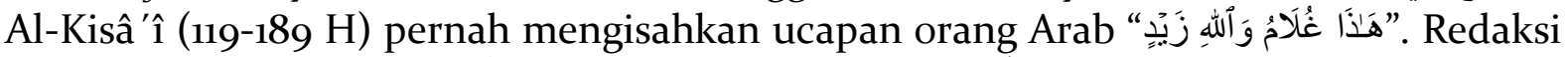

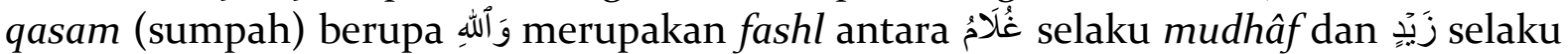
mudhâf ilaîh. ${ }^{6}$ Jadi, bila dalam ucapan umum saja diperbolehkan, maka dalam konteks syair lebih diperbolehkan. Begitu juga kaitannya dengan qiraah Ibn 'Âmir asySyâmî; bila dalam konteks Al-Qur'an diperbolehkan, maka dalam konteks syair lebih diperbolehkan. ${ }^{65}$ Sehingga, as-Suyûthî (839-911 H) menyimpulkan bahwa Madrasah Kufah membolehkan kaidah fashl menggunakan maf $\hat{u} l^{66}$ atau zharf secara absolut. ${ }^{67}$

\section{Reaksi Para Ahli di luar Madrasah Basrah dan Kufah}

Ibn Abî Maryam (W. $565 \mathrm{H}$ ) sepakat dengan Abû 'Alî al-Fârisî mengenai qabîh dan qalîl alisti'mâl. Namun, beliau menjelaskan lebih detail makna qiraah Ibn 'Âmir asy-Syâmî bahwa kata

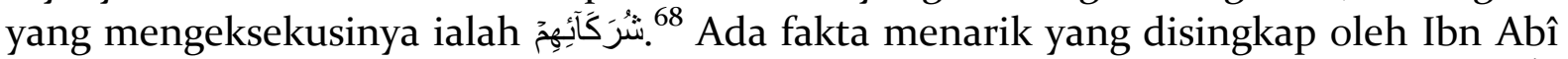

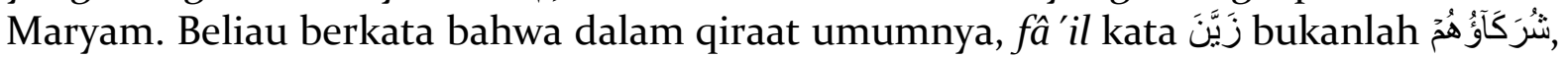
melainkan fi'l asy-Syaithân (ulah setan). Sedangkan شُرَكَاؤُ هُعْ yang berfungsi layaknya fiil. ${ }^{69}$ Sehingga secara tidak langsung, potensi fungsi kata kata

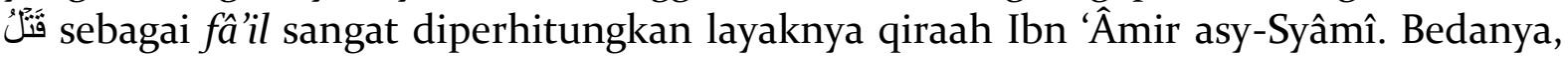

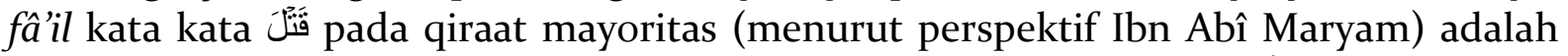
fầil yang secara tekstual dibaca raf', sedangkan dalam qiraah Ibn 'Âmir asy-Syâmî, fầil-nya berwujud mudhâfilaîh.

Beda halnya dengan Ibn Abî Maryam, Ibn Mâlik (6oo-672 H) sangat mendukung qiraah ini. Beliau berkata:

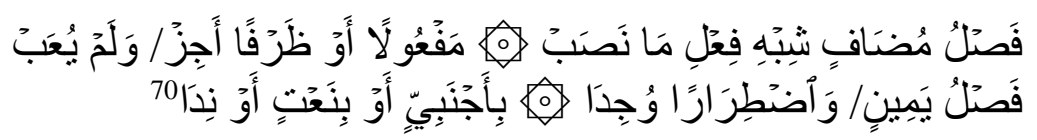

"Mudhâf" berupa "syibh fi'l" ${ }^{11}$ yang dipisah dengan kata yang di-"nashb"-kan, baik berupa "maf'ûl" atau "zharf", maka hukumnya legal. Bukan pula suatu aib bila dipisah

\footnotetext{
${ }^{63}$ Abû al-Barakât al-Anbârî, al-Inshâffî Masâ'il al-Khilâf, 382-383.

${ }^{64}$ Abû al-Barakât al-Anbârî, al-Inshâffî Masâ'il al-Khilâf, 385.

${ }^{65}$ Abû al-Barakât al-Anbârî, al-Inshâffi Masâ'il al-Khilâf, 595.

${ }^{66}$ Maf ûl bih adalah isim yang menjadi objek/sasaran aktivitas fiil. Lihat: Muhammad al- $\underline{\text { Hathtâb, }}$ Mutammimah al-Âjurrûmiyyah, cet. Ke-2 (Riyadh: Dâr ash-Shumay'î li an-Nasyr wa at-Tauzî', 2017 ), 71.

${ }^{67}$ Abû al-Hasan ash-Shafâqusî, Ghaîts an-Naf fî al-Qirâ'ât as-Sab', Makkah: Jâmi'ah Umm alQurâ, 1427 H, jld. 1, 401.

${ }^{68}$ Ibn Abî Maryam, al-Mûdhah fî Wujûh al-Qirâ'ât wa 'Ilalihâ (Beirut: Dâr al-Kutub al-'Ilmiyyah,

${ }^{69}$ Ibn Abî Maryam, al-Mûdhah fî Wujûh al-Qirâ'ât wa 'Ilalihâ, 319.

${ }^{70}$ Ibn Mâlik, Alfiyyah Ibn Mâlik dalam Muhammad bin 'Alî ash-Shabbân, Hâasyiyah ash-Shabbân,
} 2009), 318. cet. ke-2, jld. 2 (Beirut: Dâr al-Kutub al-'Ilmiyyah, 2005), 416 dan 418.

${ }^{71}$ Yang dimaksud dengan syibh fi'l (serupa dengan fiil) ialah masdar dan ism al-Fâ'il. Lihat: Ibn 'Aqîl, Syarh Ibn 'Aqîl dalam Muhammad al-Khudharî, Hâasyiyah al-Khudharî, cet. ke-2, jld. 2 (Beirut: Dâr al-Kutub al-'Ilmiyyah, 2005), 42. 
oleh kalimat sumpah. Sedangkan dalam kondisi darurat, boleh dipisah dengan "ajnabî", "na't", atau "nidâ'".

Syarahnya: fashl pada idhâfah dalam kondisi si'ah (normal) dihukumi legal bila berada pada salah satu dari empat formasi global (atau delapan formasi spesifik) di bawah ini:

a. Mudhâf berupa mashdar, mudhâf ilaîh berupa fầil-nya, dan fashl berupa:

1) Maf'ûl bih. Contohnya adalah QS. An-An'âm/6:137 versi qiraah Ibn 'Âmir asySyâmî, atau;

2) Zharf. Contohnya adalah ucapan orang Arab yang berbunyi:

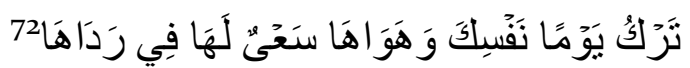

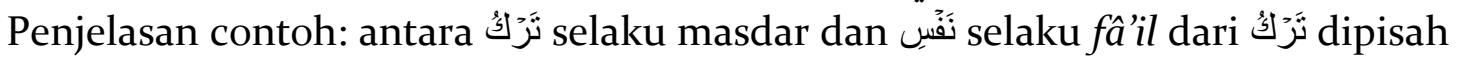
oleh يَوَئ yang berstatus sebagai zharf.

b. Mudhâf berupa shifah ${ }^{73}$, mudhâf ilaîh berupa mafûl bih pertama, dan fashl berupa:

1) Mafûl bih kedua. Contohnya adalah qiraah pada QS. Ibrâhîm/14:47 yang telah dibahas pada subbab Madrasah Basrah, ${ }^{74}$ atau;

2) Zharf. Contohnya ialah untaian bait berikut ini:

$$
\text { كَنَاحِبِ يَوَمًا سَخْرَةٍ بِعَسِيلِ }
$$

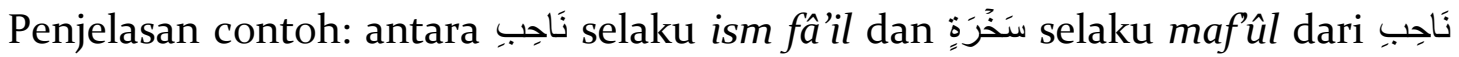
dipisah oleh يَّرَ yang berstatus sebagai zharf.

3) Syibh zharf. Contohnya adalah sabda Nabi Muhammad SAW:

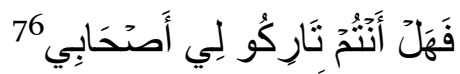

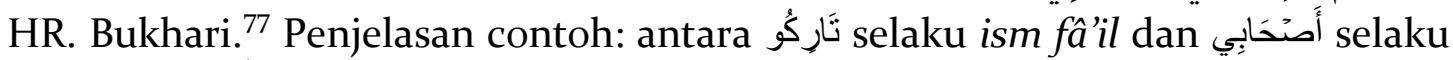
mafûl dari نَارِكُو dipisah oleh لِي yang berstatus sebagai syibh zharf, yakni jarr dan majrûr. Hadis ini diriwayatkan oleh al-Bukhârî.

c. Mudhâf dan mudhâf ilaîh dipisah oleh redaksi sumpah sebagaimana contoh yang telah disebutkan Abû 'Ubaidah pada subbab Madrasah Basrah dan al-Kisâ'î pada subbab Madrasah Kufah. ${ }^{78}$

d. Pembahasan ini tak termaktub dalam Alfiyyah Ibn Mâlik, namun termaktub dalam karya Ibn Mâlik lainnya yang berjudul Syarh al-Kâfiyyah (asy-Syâfiyah).

72 'Alî al-Asymûnî, Syarh al-Asymûnî 'alâ Alfiyyah Ibn Mâlik (Beirut: Dâr al-Kitâb al-'Arabî, 1955), 327.

73 Maksudnya ialah ism fầil yang bermakna hâll (menunjukkan kondisi terkini) atau mustaqbal (menunjukkan kondisi yang akan datang). Lihat: Muhammad bin 'Alî ash-Shabbân, Hâasyiyah ashShabbân, 418.

${ }^{74}$ Menurut analisis penulis, qiraah ini sejatinya bermasalah. Alasannya, sumber referensi qiraah ini bermuara kepada Ma'ânî al-Qur'ân wa I'râbuh karya az-Zajjâj tanpa menyebutkan siapa perawinya. Beliau hanya mengatakan bahwa bacaan ini masuk kategori syâdzdz dan radî'ah. Beliau juga mengatakan bawah mudhâf dan mudhâf ilaîh tidak boleh terpisah. Yang perlu diingat, beliau adalah salah satu punggawa Madrasah Basrah yang menolak hukum fashl qiraah Ibn 'Âmir asy-Syâmî. Penj.

75 'Alî al-Asymûnî, Syarh al-Asymûnî 'alâ Alfiyyah Ibn Mâlik, 327.

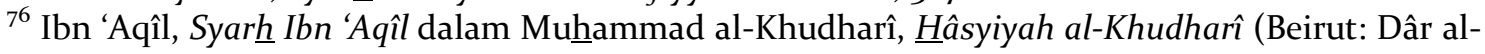
Kutub al-'Ilmiyyah, 2005), 42.

${ }^{77}$ Muhammad al-Bukhârî, Shahîh al-Bukhârî (Beirut: Dâr al-Kutub al-'Ilmiyyah, 2004), 667, hadis no. 3661 .

78 'Alî al-Asymûnî, Syarh al-Asymûnî 'alâ Alfiyyah Ibn Mâlik, 328. 
Pembahasan tersebut ialah terpisahnya mudhâf dan mudhâf ilaîh oleh kata إَِّّ. Contoh:

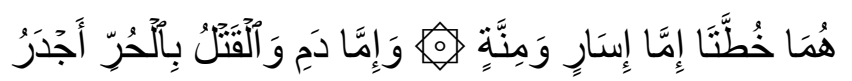

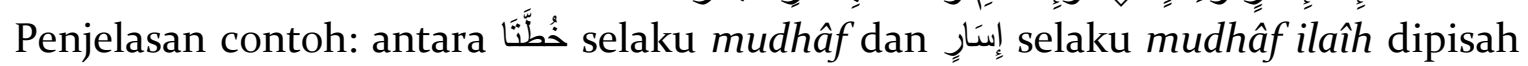
oleh إَِّّ. 79

Masih menurut Ibn Mâlik, fashl pada idhâfah yang khusus dalam ranah syair hanya terdapat di tiga formasi berikut ini:

a. Mudhâf dan mudhâf ilaîh dipisah oleh ajnabî; yakni kata yang tidak dipengaruhi mudhâf. ${ }^{80}$ Contoh:

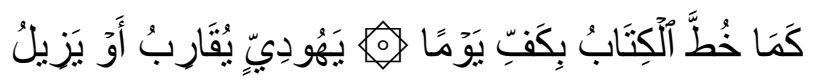

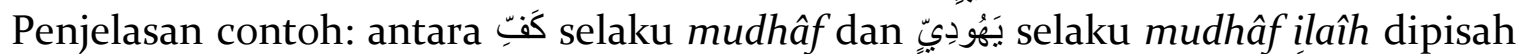

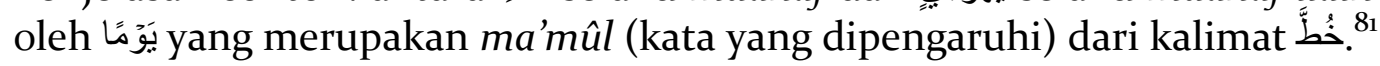

b. Mudhâf dan mudhâf ilaîh dipisah oleh na't/shifah. Contoh:

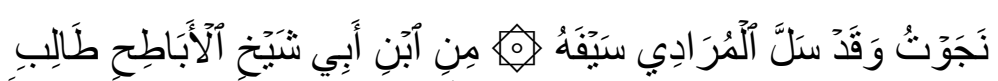

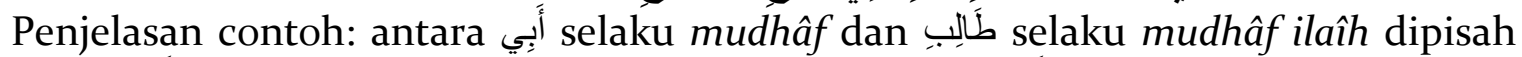

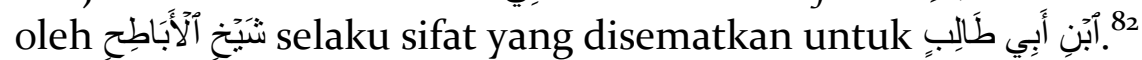

c. Mudhâf dan mudhâf ilaîh dipisah oleh nidâ ${ }^{\prime 83}$. Contoh:

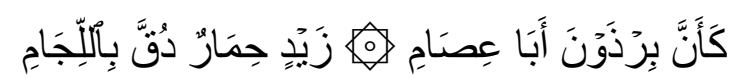

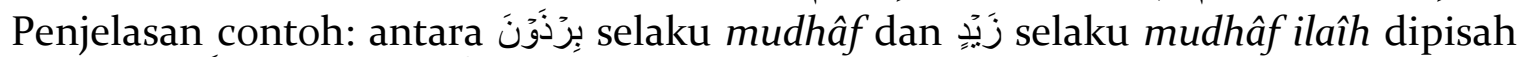
oleh أَبَا عِصَّامِ selaku nida ${ }^{\prime}{ }^{84}$

Tidak berhenti di situ, dalam Syarh at-Tashîl, Ibn Mâlik tidak lagi membedah keabsahan qiraah Ibn 'Âmir asy-Syâmî ini, melainkan menjadikannya sebagai model untuk kebolehalan memisah idhâfah dengan mafûl bih. Beliau berkata: "Dalil terkuat (dari kebolehan fashl berupa kata non-raf ${ }^{85}$ yang dipengaruhi mudhâf) ialah bacaan Ibn 'Âmir radhyallâh 'anh (QS. Al-An'âm/6:137) karena bacaan ini telah ditetapkan kemutawâtir-annya, telah disandarkan kepada sosok yang dipercaya sebagai orang Arab, dan jangan lupa bahwa beliau adalah seorang tabiin besar yang meniti jalan orangorang yang fasih yang tidak memiliki rekam jejak gejala lahn, cukuplah 'Utsmân bin 'Affân radhyallâh 'anh sebagai salah satu gurunya menjadi bukti dari orang-orang yang diikuti Ibn 'Âmir asy-Syâmî" ${ }^{66}$ Lanjutnya: "Bacaan Ibn "Âmir asy-Syâmî sangat

79 'Alî al-Asymûnî, Syarh al-Asymûnî 'alâ Alfiyyah Ibn Mâlik, 328.

80 Muhammad al-Khudharî, Hâasyiyah al-Khudharî, cet. ke-2, jld. 2 (Beirut: Dâr al-Kutub al'Ilmiyyah, 2005), 43.

${ }^{81}$ Ibn 'Aqîl, Syarh Ibn 'Aqîl dalam Muhammad al-Khudharî, Hâsyiyah al-Khudharî, 44.

${ }^{82}$ Lihat: Badr ad-Dîn Muhammad bin Jamâl ad-Dîn Muhammad bin Mâlik, Syarh Ibn an-Nâzhim 'alâ Alfiyyah Ibn Mâlik, cet. ke-3 (Beirut: Dâr al-Kutub al-'Ilmiyyah, 2019), 292-293.

${ }^{83}$ Nidâ' ialah seruan menggunakan akses huruf $y \hat{a}{ }^{\prime}$ atau salah satu temannya. Lihat: Muhammad al-Khudharî, Hâsyiyah al-Khudharî, 166.

${ }^{84}$ Badr ad-Dîn Muhammad bin Jamâl ad-Dîn Muhammad bin Mâlik, Syarh Ibn an-Nâzhim 'alâ Alfiyyah Ibn Mâlik, 292-293.

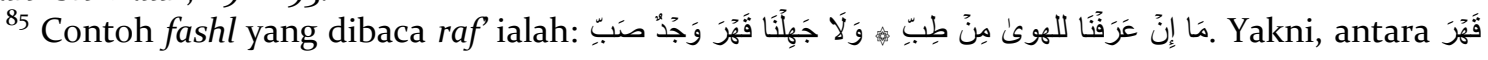

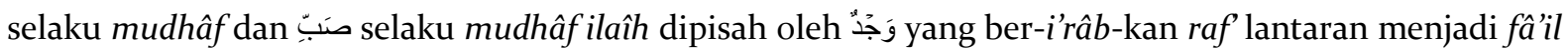
dari mudhâf. Lihat: Ibn Mâlik, Syarh at-Tashîl, Giza: Hajar, cet. ke-1, 1990, jld. 3, hal. 274.

${ }^{86}$ Ibn Mâlik, Syarh at-Tashîl, Giza: Hajar, cet. ke-1, 1990, jld. 3, hal. 276-277. 
diperbolehkan dalam standar sintaksis Arab, yakni dengan mendatangkan fashl antara mudhâf dan fầil-nya mudhâf (yakni mudhâf ilaîh). Kebolehan ini dilandasi tiga hal:

a. Status fashl (sesuai contoh) adalah fadhlah ${ }^{87}$, maka hal ini sah-sah saja, mengingat peran fadhlah tidaklah terlalu vital.

b. Fashl (sesuai contoh) bukanlah ajnabî, karena ia memiliki korelasi dengan mudhâf (yakni sebagai mafûl bih-nya mudhâf).

c. Fashl sejatinya harus ta'khîr (diakhirkan) karena adanya mudhâf ilaîh, namun ia berhasil didahulukan karena mudhâf ilaîh ini hanyalah fầil dari persepektif makna (adapun dari pesepektif teks, sudah jelas bahwa ia merupakan mudhâf ilaîh).

Maka, sekalipun masyarakat Arab tidak menggunakan fashl layaknya qiraah Ibn 'Âmir asy-Syâmî ini, kias tetap membolehkannya. Alasannya karena dalam ranah syair, mereka kerap menggunakan fashl kategori ajnabî. Maka, sudah barang tentu penggunaan fashl yang non-ajnabî memiliki kasta yang lebih istimewa." ${ }^{88}$ Realitanya, kaidah sintaksis Arab yang tak sesuai kias saja masih bisa diterima, selagi sahih penukilannya. Sebut saja contoh أَسْنَحَوَذَ yang secara kaidah mestinya dibaca أَتَنَحَاذَ Apalagi bacaan Ibn 'Âmir asy-Syâmî yang secara penukilan telah dihukum sahih sanadnya, ditambah terlegitimasinya kaidah (sintaksis Arab) yang digunakan. ${ }^{89}$

Sebelum Ibn Mâlik, sudah ada pendahulunya sesama ulama asal Andalusia yang juga terkenal vokal mengkawal qiraah Ibn 'Âmir Asy-Syâmî. Beliau adalah al-Qâsim asy-Syâthibî (W. 590 H). Dalam Hirz al-Amânî wa Wajh at-Tahânî, al-Qâsim asySyâthibî berkata:

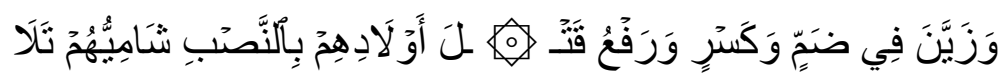

Bacaan bumi Syam (Ibn 'Âmir asy-Syâmî) ialah men-dhammah-kan dan mengkasrahkan

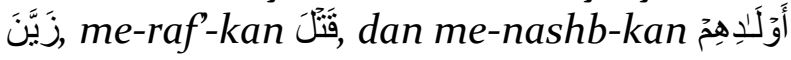

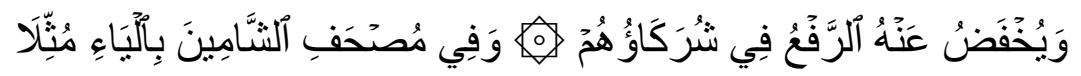

meng-khafdh-kan شُرَكَاؤُ هُمْ yang (sejatinya dibaca) raf" (karena) dalam mushaf penduduk Syam tertulis menggunakan yâ ${ }^{\prime}$

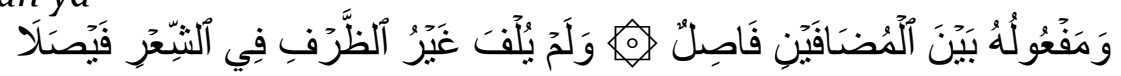

Mafûl-nya menjadi pemisah di antara idhâfah yang mana (menurut ahli sintaksis Arab) fashl selain zharf tidak ditemukan dalam syair ${ }^{\circ}$

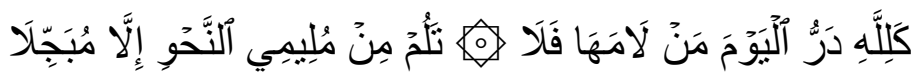

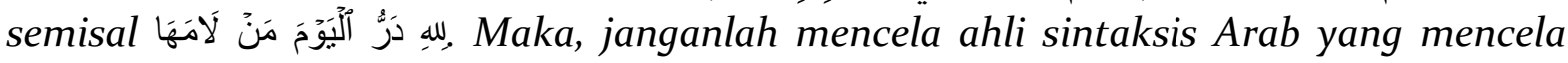
kecuali bila yang mencela itu menjahilkan (objek yang dicela)

Syarah: Syair ini merupakan contoh dari kalangan tersebut bahwa fashl (آََََّْم) untuk syair hanya berupa zharf. Kemudian, para pembaca hendaknya tidak mencela balik para ahli sintaksis Arab tersebut yang menganggap qiraah Ibn 'Âmir asy-Syâmî telah mencederai kias yang masyhur. Namun, celalah mereka yang mengklaim Ibn 'Âmir asy-Syâmî sebagai sosok yang jahil. Padahal, Ibn 'Âmir asy-Syâmî tidak

${ }^{87}$ Fadhlah ialah isim yang dihadirkan demi menyempurnakan makna suatu rangkaian kata, namun ia bukan rukun dari rangkaian tersebut. Lihat: Mushthafâ al-Ghulâyînî, Jâmi' ad-Durûs al'Arabiyyah (Beirut: al-Maktabah al-'Ashriyyah, 2005), 25.

88 Ibn Mâlik, Syarh at-Tashîl, 277.

${ }^{89}$ Ibn Mâlik, Syarh al-Kâfiyyah asy-Syâfiyah, t.tp: Dâr al-Ma'mûn li at-Turâts, cet. ke-1, 1982, jld. 2, hal. 981-982.

$9^{\circ}$ Abû Syâmah ad-Dimasyqî, Ibrâz al-Ma'ânî (Beirut: Dâr al-Kutub al-'Ilmiyyah, t.th), 462. 
memproduk suatu bacaan dari dirinya sendiri, melainkan dari penukilan (periwayatan) yang sahih. ${ }^{91}$

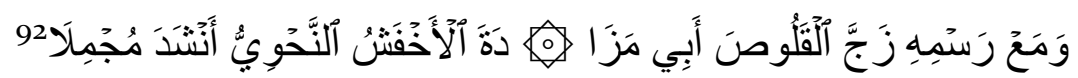

Al-Akhfasy selaku ahli sintaksis Arab memiliki nasyid (syair) nan indah yang

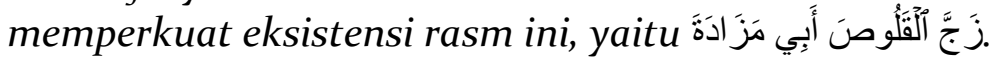

Syarah: Maksud dari memperkuat rasm-nya ialah adanya huruf yâ ' pada kata yang terletak setelah mafûl bih; أَلَقُوصَ yang membuatnya menjadi mudhâf ilaîh dari kata jyang dibaca nashb karena menyandang predikat maf ûl muthlaq ${ }^{94}$.

Dalam karya lainnya yang berjudul 'Aqîlah Atrâb al-Qashâid, beliau berkata:

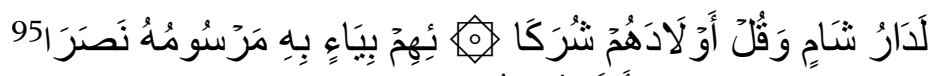

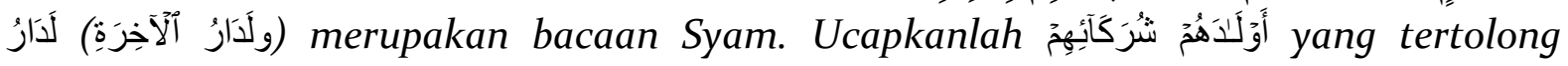
(legitimasinya) sebab rasm (huruf hamzah) berupa huruf yâ' '. berbunyi:

Kembali ke Ibn Mâlik. Pembelaan beliau ditutup dengan pernyataannya yang

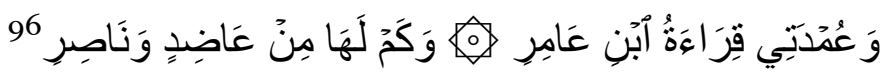
Saya berpegang teguh pada qiraah Ibn 'Âmir. Betapa banyak orang yang pro dan menolong qiraahnya.

Klaim banyaknya yang pro dan menolong qiraah Ibn 'Âmir asy-Syâmî nyatanya memang benar adanya. Mengingat segala konter terhadap qiraah terkait yang beliau alamatkan kepada para kritikus nyatanya mengikuti minhaj Madrasah Kufah. Asbab jasanya, tiap qiraah dapat diketahui argumentasinya yang menghasilkan kembalinya nama baik para qari. ${ }^{97}$ Selain mengikuti minhaj Madrasah Kufah, beliau juga meniti jalan al-Qâsim asy-Syâthibî yang menjadi pembela qiraah Ibn 'Âmir asy-Syâmî.

\section{Analisis}

Konklusi pembahasan QS. Al-An'âm/6:137 ialah adanya indikasi bahwa Ibn Jarîr ath-Thabarî menghakimi bacaan Al-Qur'an menggunakan uslûb (gaya bahasa) Arab, seolah-olah uslûb bahasa Arab merupakan sumber primer dan Al-Qur'an diletakkan sebagai sumber sekunder. Beliau seakan ingin mengajarkan Al-Qur'an bagaimana cara membangun susunan ungkapan dalam Al-Qur'an. Padahal, Dalam konteks sintaksis

91 Para pembaca hendaknya tidak mencela balik para ahli sintaksis Arab tersebut yang menganggap qiraah Ibn 'Âmir asy-Syâmî telah mencederai kias yang masyhur. Namun, celalah mereka yang mengklaim Ibn 'Âmir asy-Syâmî sebagai sosok yang jahil. Padahal, Ibn 'Âmir asy-Syâmî tidak memproduk suatu bacaan dari dirinya sendiri, melainkan dari penukilan (periwayatan) yang sahih. Lihat: Sayyid Lâsyîn dan Khâlid al-'Ilmî, Taqrîb al-Ma'ânî (Madinah: Maktabah Dâr az-Zamân, 2011 ), 422.

92 Al-Qâsim bin Fîrruh asy-Syâthibî, Hirz al-Amânî wa Wajh at-Tahânî, cet. ke-1 (Madinah: Maktabah Dâr Ibn al-Jazarî, 2011), 53, bait no. 670-674.

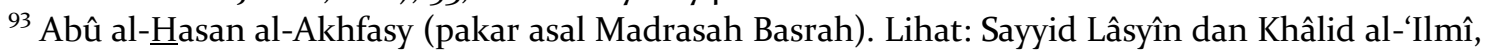
Taqrîb al-Ma'ânî, 422.

94 Mafûl muthlaq ialah masdar fadhlah yang berfungsi menegaskan 'âmil-nya atau menjelaskan variasi 'âmil-nya atau menjelaskan jumlah 'âmil-nya. Lihat: Ibn Hisyâm al-Anshârî, Syarh Syudzûr adzDzahab, , cet. ke-1 (Beirut: Dâr al-Fikr, 2009), 296.

95 Al-Qâsim bin Fîrruh asy-Syâthibî, 'Aqîlah Atrâb al-Qashâid fî Asnâ al-Maqâshid, 7.

${ }^{6}$ Ibn Mâlik, al-Kâfiyyah asy-Syâfiyah, al-Kâfiyyah asy-Syâfiyah, cet. ke-1 (t.tp: Dâr al-Ma'mûn li at-Turâts, 1982), 979.

97 ‘Abd al-Mun'im Aḥmad Huraidî dalam Ibn Mâlik, Syarh al-Kâfiyyah asy-Syâfiyah, 982. 
Arab, Al-Qur'an lah yang bertugas sebagai barometer; sumber rujukan, bukan sebaliknya. ${ }^{98}$ Ibn al-Qâshih (W. 801 H) menyatakan bahwa bacaan qiraah Ibn 'Âmir asy-Syâmî pada ayat ini adalah bacaan yang valid yang tak layak bagi seorang muslim untuk mencercanya. ${ }^{99}$

Berbeda dengan Ibn Jarîr ath-Thabarî, Ibn Katsîr ad-Dimasyqî, Mujâhid bin Jabr, dan penulis Tafsîr al-Jalâlaîn dari persepektif makna, menurut Jârullâh azZamakhsyarî, kalimat شُرَكَأَهُ هُ ن memiliki makna yang lebih luas, yakni bisa bermaka para setan atau sanadah (pengabdi) setan. ${ }^{100}$ Begitu juga menurut al-Alûsî (1217-1270 H) yang berpendapat bahwa شُرَكَاَوَُهُ Sedangkan Hamka (1908-1981) memiliki pandangan yang lebih spesifik. Menurutnya,

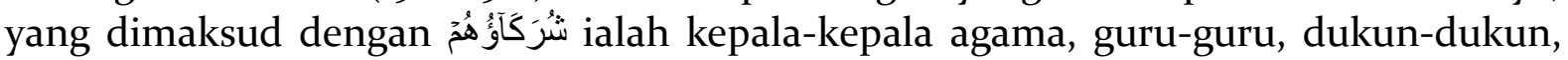
dan pendeta-pendeta mereka yang telah membujuk rayu agar membunuh anak-anak mereka dengan alasan takut miskin atau bahkan alasan spirit berkorban nyawa demi agama. ${ }^{102}$ Sehingga kekhawatiran Ibn Jarîr ath-Thabarî dari segi makna dapat ditepis dengan pendapat-pendapat ini. Guna menindaklanjuti pernyataan Ibn Jarîr athThabarî yang menyatakan "Sebagian qari penduduk Syam", maka akan dipaparkan seluruh cara baca QS. Al-An’âm/6:137 yang dibaca di bumi Syam beserta nama-nama perawi internal bumi Syam:

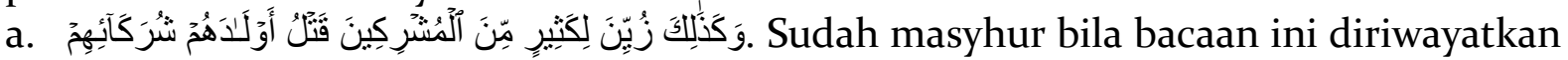
oleh Ibn 'Âmir asy-Syâmî.

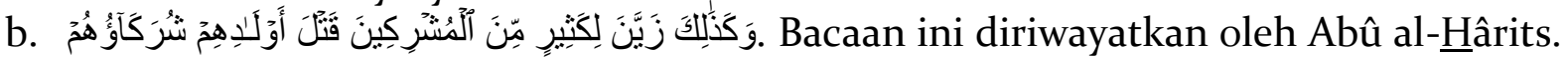
Nama Abû al-Hârits penulis cantumkan di sini karena berangkat dari data dalam kitab al-Kâmil. Dalam kitab tersebut, al-Hadzalî selaku penulis mencantumkan nama Abû al-Hârits sebagai kalangan Damaskus yang tidak membaca sesuai qiraah Ibn 'Âmir asy-Syâmî. Kemudian al-Hadzalî meng-generalisasi bahwa seluruh imam qiraat selain Ibn 'Âmir asy-Syâmî, al-Hasan, dan Ibn Miqsam (265-354 H) hanya membaca sesuai variasi ini. ${ }^{103}$

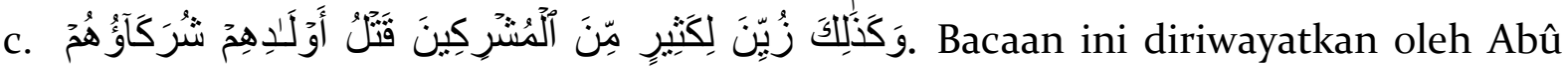
'Abd al-Malik. ${ }^{104}$

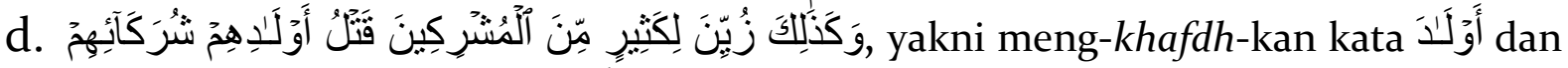
memposisikan kalimat شُرَكَ Zahrâwî (W. 427 H) tanpa menyebutkan nama spesifik perawi bacaan ini. Beliau hanya mengungkapan bahwa bacaan ini dibaca oleh sebagian kalangan bumi Syam. ${ }^{106}$

${ }^{98}$ Labîb as-Sa'îd, Difâ' 'an al-Qirâ 'ât al-Mutawâtirah fì Muwâjahah ath-Thabarî al-Mufassir (Kairo: Dâr al-Ma'ârif, 1978), 74, 77.

${ }^{99}$ Ibn al-Qâshihh, Talkhîsh al-Fawâ'id wa Taqrîb al-Mutabâ’id, cet. ke-1 (Kairo: Dâr as-Salâm, 2011), 58.

${ }^{100}$ Jârullâh Az-Zamakhsyarî, Tafsîr al-Kasysyâf, cet. ke-3 (Beirut: Dâr al-Ma'rifah, 2009), 347.

${ }^{101}$ Mahmûd al-Alûsî, Rûh al-Ma'ânî, jld. 8 (Beirut: Dâr at-Turâts al-'Arabiyyah, t.th), 32.

${ }^{102}$ Hamka, Tafsir Al Azhar, juz 8 (Jakarta: Pustaka Panjimas, 1982), 71.

${ }^{103}$ Abû al-Qâsim Yûsuf al-Hadzalî, al-Kâmil fi al-Qirâ'ât al-Khamsîn, cet. ke-1, jld. 4 (Kairo: Maktabah Aulâd asy-Syaîkh li at-Turâts, 2016), 217.

${ }^{104}$ Ibn 'Athiyyah, al-Muharrar al-Wajîz fi Tafsîr al-Kitâb al-'Azîz (Beirut: Dâr al-Kutub al'Ilmiyyah, 2001), 349 .

${ }^{105}$ Ash-Shâwî, Hâasyiyah ash-Shâwî (Beirut: Dâr al-Fikr, 2004), 61.

${ }^{106}$ Ibn 'Athiyyah, al-Muharrar al-Wajîz fì Tafsîr al-Kitâb al-'Azîz, 350. 


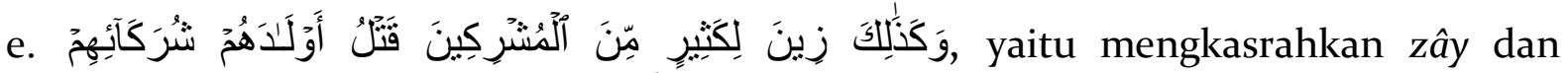

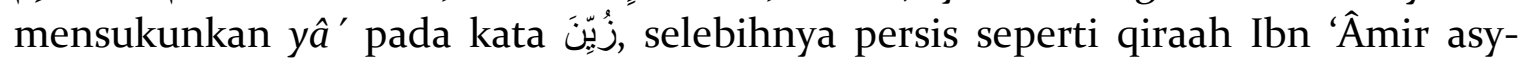
Syâmî. ${ }^{107}$ Fakta mengungkapkan bahwa bacaan ini juga diriwayatkan dari Ibn 'Âmir asy-Syâmî. ${ }^{108}$

Dari lima cara baca ini, hanya dua qiraah pertama berstatus mutawâtir (khusus bacaan kedua, ia mutawâtir bukan karena diriwayatkan oleh Abû al-Hârits, melainkan mutawâtir karena diriwayatkan oleh sembilan dari qiraat 'asyr). Selebihnya merupakan qiraat yang berstatus syâdzdz. ${ }^{109}$

\section{Kesimpulan}

Dari seluruh pemaparan di atas dapat disimpulkan bahwa ke-mutawâtir-an qiraah Ibn 'Âmir tak dapat tereduksi walau dalam qiraah ini terdapat kontroversi seputar eksistensi fashl antara dua komponen idhâfah, karena seluruh kritikan yang disematkan kepada qiraah Ibn 'Âmir nyatanya tidak ada yang mengusik seputar kemutawâtir-annya. Terlebih tidak semua ahli sintaksis Arab menolak formula ini. Maka hal ini sejalan dengan spirit suatu kaidah fikih yang berbunyi:

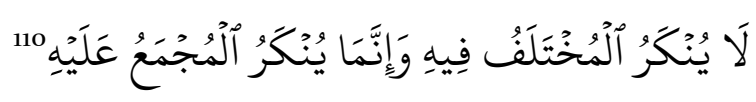

Janganlah ingkari perihal yang mengandung perdebatan. Namun, ingkarilah perihal yang telah disepakati (ketidakbolehannya).

Kesimpulan tambahan yang penulis temukan ialah adanya kritikan para mufasir dan ahli qiraat yang dilontarkan untuk qiraat Ibn 'Âmir asy-Syâmî pada ayat di atas bermuara pada pendapat sintaksis Arab yang dikemukakan para ahli Madrasah Basrah. Mereka (Madrasah Basrah) telah membuat rumusan kaidah sebelum mencari referensi secara komprehensif, khususnya referensi qiraat. Beda halnya dengan Madrasah Kufah yang terlebih dahulu mencari referensi (qiraat) sebelum mengkristalkan sebuah kaidah.

${ }^{107}$ Ash-Shâwî, Hîasyiyah ash-Shâwî (Beirut: Dâr al-Fikr, 2004), 61.

${ }^{108}$ Abû Hayyân, Tafsîr al-Bahr al-Muhîth (Beirut: Dâr al-Kutub al-'Ilmiyyah, 1993), 233.

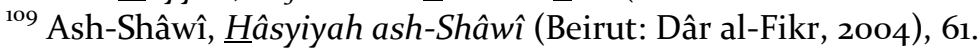

${ }^{110}$ Jalâl ad-Dîn as-Suyûthî, al-Asybâh wa an-Nazhâ'ir fì Qawầid wa Furû' Fiqh asy-Syâfi'iyyah (Beirut: Dâr al-Kutub al-'Ilmiyyah, 2005), 341. 


\section{DAFTAR PUSTAKA}

'Âbidîn, Anwar Shubhîi Muhammad. alikhtishâr fî al-Qirâ'ât al-'Asyr. Tanta: Dâr ashShahâbah li at-Turâts. Cet. ke-1, 2013.

Abû Hayyân. Tafsîr al-Bahrr al-Muhîth. Beirut: Dâr al-Kutub al-'Ilmiyyah. Cet. ke-1, 1993.

Al-Ahdal, Muhammad. al-Kawâkib ad-Durriyyah 'alâ Mutammimah al-Âjurrûmiyyah. Kairo: Maktabah al-Hady al-Muhammadî. Cet. ke-2, 2016.

Al-Ahwâzî, Abû 'Alî al-Hasan. al-Wajîz. Beirut: Dâr al-Gharb al-Islâmî. Cet. ke-1, 2002.

Al-Anbârî, Abû al-Barakât. al-Inshâf fì Masâ'il al-Khilâf. Beirut: Dâr al-Kutub al'Ilmiyyah. Cet. ke-3, 2016.

Al-Alûsî, Mahmûd. Rûh al-Ma'ânî. Beirut: Dâr at-Turâts al-'Arabiyyah, t.th.

Al-Anshârî, Abû Ja'far Aḥmad. al-Iqnâ' fí al-Qirâ' ât as-Sab'. Tanta: Dâr ash-Shahâbah li at-Turâts, 2003.

Al-Anshârî, Ibn Hisyâm. Syarh Syudzûr adz-Dzahab. Beirut: Dâr al-Fikr. Cet. ke-1, 2009.

Al-Ashfahânî, Abû Bakr bin Mihrân. al-Mabsûth fì al-Qirâ'ât al-'Asyr. Jeddah: Dâr alQiblah li ats-Tsaqâfah al-Islâmiyyah. Cet. ke-2, 1988.

Al-Asymûnî, 'Alî. Syarh al-Asymûnî 'alâ Alfiyyah Ibn Mâlik. Beirut: Dâr al-Kitâb al'Arabî. Cet. ke-1, 1955.

Bin Jabr, Mujâhid. Tafsîr al-Imâm Mujâhid bin Jabr. Kairo: Dâr al-Fikr al-Islâmî alHadîtsah. Cet. ke-1, 1989.

Bin Mâlik, Badr ad-Dîn Muhammad bin Jamâl ad-Dîn Muhammad. Syarh Ibn anNâzhim 'alâ Alfiyyah Ibn Mâlik. Beirut: Dâr al-Kutub al-'Ilmiyyah Cet. ke-3, 2019.

Bin Qanbar. Amr bin 'Utsmân. Kitâb Sîbawaîh. Kairo: Maktabah al-Khânjî. Cet. ke-6, 2013.

Bin al-Qâshihn, 'Alî bin 'Utsmân bin Muhammad. Talkhîsh al-Fawâid wa Taqrîb alMutabâ'id. Kairo: Dâr as-Salâm. Cet. ke-1, 2011.

Al-Bukhârî, Muhammad. Shahîh $\underline{h}$ al-Bukhârî, Beirut: Dâr al-Kutub al-'Ilmiyyah. Cet. ke4, 2004.

Ad-Dânî, Abû 'Amr. at-Taisîr fî al-Qirâ'ât as-Sab'. Tanta: Dâr ash-Shahâbah li atTurâts, 2006.

Ad-Dimasyqî, Abû Syâmah. Ibrâz al-Ma'ânî. Beirut: Dâr al-Kutub al-'Ilmiyyah, t.th.

Ad-Dimasyqî, Ibn Katsîr. Tafsîr al-Qur'ân al-'Azhîm. Beirut: Dâr al-Fikr, 2005.

Adz-Dzahabî, Muhammad. Ma'rifah al-Qurrâ' al-Kibâr. Tanta: Dâr ash-Shahâbah li atTurâts. Cet. ke-1, 2008.

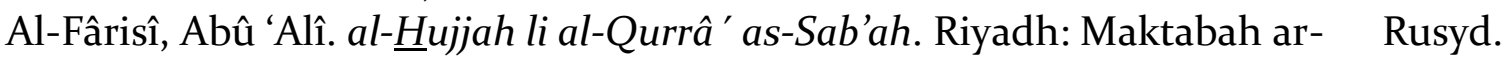
Cet. ke-2, 2018. 
Al-Ghulâyînî, Mushthafâ. Jâmi' ad-Durûs al-'Arabiyyah. Beirut: al-Maktabah al'Ashriyyah. Cet. ke-1, 2005.

Al-Hadzalî, Abû al-Qâsim Yûsuf. al-Kâmil fi al-Qirâ'ât al-Khamsîn. Kairo: Maktabah Aulâd asy-Syaîkh li at-Turâts. Cet. ke-1, 2016.

Hamka. Tafsir Al Azhar. Jakarta: Pustaka Panjimas, 1982.

Al-Harbî, 'Abd al-'Azîz bin 'Alî. Taujîh Musykil al-Qirâ'ât al-'Asyriyyah al-Farsyiyyah. Beirut: Dâr Ibn Hazm. Cet. ke-1, 2012.

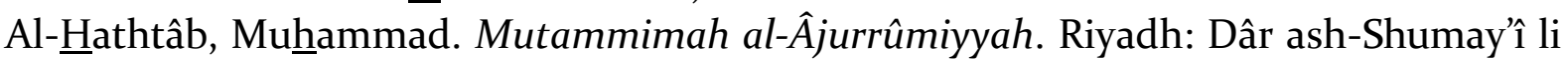
an-Nasyr wa at-Tauzî̀. Cet. ke-2, 2017.

Huraidî, 'Abd al-Mun'im Aḥmad dalam Ibn Mâlik. Syarh al-Kâfiyyah asy-Syâfiyah. t.tp: Dâr al-Ma' mûn li at-Turâts. Cet. ke-1, 1982.

Ibn Abî Maryam. al-Mûdhah fî Wujûh al-Qirâ'ât wa 'Ilalihâ. Beirut: Dâr al- Kutub al'Ilmiyyah. Cet. ke-1, 2009.

Ibn 'Aqîl. Syarh Ibn 'Aqîl dalam al-Khudharî, Muhammad. Hâasyiyah al-Khudharî. Beirut: Dâr al-Kutub al-'Ilmiyyah. Cet. ke-2, 2005.

Ibn 'Athiyyah. al-Muharrar al-Wajîz fî Tafsîr al-Kitâb al-'Azîz. Beirut: Dâr al-Kutub al'Ilmiyyah. Cet. ke-1, 2001.

Ibn al-Jazarî, Ghâyah an-Nihâyah fi Thabaqât al-Qurrâ'. Kairo: Maktabah al-Khânjî. Cet. ke-1, 2010.

. Muhammad. an-Nasyr fi al-Qirâ'ât al-'Asyr. Kairo: Maktabah ash-Shafâ. Cet. ke-1, 2014.

Ibn Jinnî. al-Muhtasab, t.tp: Dâr Sazkîn. Cet. ke-2, 1986.

Ibn Khâlawaîh. al- $\underline{H}$ ujjah fi al-Qirâ 'ât as-Sab'. Kairo: Dâr Ibn al-Jauzî. Cet. ke-1, 2013.

Ibn Mâlik. Alfiyyah Ibn Mâlik dalam ash-Shabbân, Muhammad bin 'Alî. Hâasyiyah ashShabbân. Beirut: Dâr al-Kutub al-'Ilmiyyah. Cet. ke-2, 2005.

al-Kâfiyyah asy-Syâfiyah dalam Ibn Mâlik. Syarh al-Kâfiyyah asy-Syâfiyah. t.tp: Dâr al-Ma' mûn li at-Turâts. Cet. ke-1, 1982.

Syarh al-Kâfiyyah asy-Syâfiyah. t.tp: Dâr al-Ma'mûn li at-Turâts. Cet. ke-1, 1982

Syarh at-Tashîl. Giza: Hajar. Cet. ke-1, 1990.

Ismâ'îl, Sya'bân Muhammad. al-Qirâ'ât; Ahkâmuhâ wa Mashdaruhâ. Kairo: Dâr $\quad$ asSalâm. Cet. ke-4, 2008.

Kahîllah, Muhammad ad-Dusûqî Amîn. Syarh asy-Syâthibiyyah. Kairo: Dâr as-Salâm. Cet. ke-1, 2013.

Al-Kalbî, Abû al-Qâsim. at-Tashîl li 'Ulûm at-Tanzîl. Beirut: Dâr al-Kutub al-'Ilmiyyah. Cet. ke-1, 1995.

Al-Khudharî, Muhammad. Hâasyiyah al-Khudharî. Beirut: Dâr al-Kutub al-'Ilmiyyah. Cet. ke-2, 2005 .

Lâsyîn, Sayyid dan al-'Ilmî, Khâlid. Taqrîb al-Ma'ânî. Madinah: Maktabah Dâr azZamân. Cet. ke-8, 2011

Al-Mahallî Jalâl ad-Dîn dan as-Suyûthi, Jalâl ad-Dîn. Tafsîr al-Jalâlaîn, dalam ash-

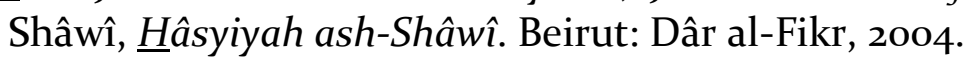

Al-Qalânisî, Muhammad bin al-Husaîn. Irsyâd al-Mubtadî wa Tadzkirah al-Muntahî. Beirut: Dâr al-Kutub al-'Ilmiyyah. Cet. ke-1, 2007.

Al-Qurasyî, Hâtim bin 'Âbid. "Daf' ali'tirâdh 'an Qirâ'ah Ibn 'Âmir: Zuyyin li Katsîr min al-Musyrikîn Qatl Awlâdahum Syurakâ'ihim.” Jurnal Dâr alManzhûmah, Vol. 04 No. 6 Tahun 2015, hal. 5. 
As-Sa'îd, Labîb. Difầ' 'an al-Qirâ 'ât al-Mutawâtirah fî Muwâjahah athThabarî al-Mufassir. Kairo: Dâr al-Ma'ârif, 1978.

Ash-Shabbân, Muhammad bin 'Alî. ㅂâsyiyah 'alâ Syarh as-Sullam. Mesir: Mathba'ah

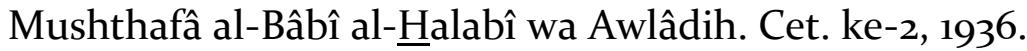

Ash-Shafâqusî, Abû al-Hasan. Ghaîts an-Naf' fì al-Qirâ'ât as-Sab'. Makkah: Jâmi'ah Umm al-Qurâ, $1427 \mathrm{H}$.

Ash-Shâwî. Hâasyiyah ash-Shâwî. Beirut: Dâr al-Fikr, 2004.

As-Suyûthî, Jalâl ad-Dîn. al-Asybâh wa an-Nazhâ'ir fî Qawâ'id wa Furû' Fiqh asySyâfi'iyyah. Beirut: Dâr al-Kutub al-'Ilmiyyah. Cet. ke-3, 2005.

Asy-Syahrazûrî, Al-Mubârak. al-Mishbâh az-Zâhir. Beirut: Dâr al-Kutub al- 'Ilmiyyah. Cet. ke-1, 2008.

Asy-Syâthibî, Al-Qâsim bin Fîrruh. Hirz al-Amânî wa Wajh at-Tahânî. Madinah: Maktabah Dâr Ibn al-Jazarî. Cet. ke-1, 2011.

Ath-Thabarî, Ibn Jarîr. Tafsîr ath-Thabarî. Kairo: Dâr as-Salâm. Cet. ke-4, 2009.

Al-'Ukbarî, Abû al-Baqâ'. I'râb al-Qirâ'ât asy-Syawâdz. Tanta: Dâr ash-Shahâbah li atTurâts. Cet. ke-1, 2009.

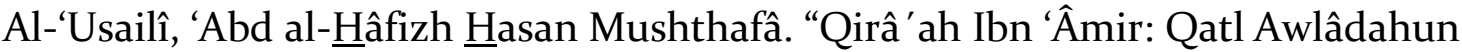
Syurakâ'ihim." Majallah Kuliyyah al-Lughah al- 'Arabiyyah bi al-Manûfiyyah, Vol. 13 Tahun 1992, hal. 553-554.

Al-Wâsithî, Ibn al-Wajîh. al-Kanz fí al-Qirâ'ât al-'Asyr. Beirut: Dâr al- $\quad$ Kutub al'Ilmiyyah. Cet. ke-1, 1998.

Az-Zajjâj, Abû Ishâq. Ma'ânî al-Qur'ân wa I'râbuh. Beirut: 'Âlam al-Kutub. Cet. ke-1, 1988.

Az-Zamakhsyarî, Jârullâh. Tafsîr al-Kasysyâf. Beirut: Dâr al-Ma'rifah. Cet. ke-3, 2009. 